\title{
The Heralds of Zionism as Theological Revolutionaries
}

\author{
Amir Mashiach
}

check for updates

Citation: Mashiach, Amir. 2021. The Heralds of Zionism as Theological Revolutionaries. Religions 12: 1100. https://doi.org/10.3390/rel12121100

Academic Editor: Hans Zollner

Received: 26 October 2021

Accepted: 26 November 2021

Published: 14 December 2021

Publisher's Note: MDPI stays neutral with regard to jurisdictional claims in published maps and institutional affiliations.

Copyright: (C) 2021 by the author. Licensee MDPI, Basel, Switzerland. This article is an open access article distributed under the terms and conditions of the Creative Commons Attribution (CC BY) license (https:/ / creativecommons.org/licenses/by/ $4.0 /)$.
The School of Education, Ariel University, Ariel 40700, Israel; amirma@ariel.ac.il

\begin{abstract}
In historiographical research, there is an approach that perceives the ideologues who preceded the Hovevei Zion movement (1881) and the Zionist movement (1896) as "heralds of Zionism". These ideologues operated, or at least proposed the idea of the Jews' return to the Land of Israel and establishment a political entity in the Land, beginning from the 1860s. The researchers are divided, however, on the identification of the heralds. Some locate them even earlier, in the 17 th century, while others deny their very existence. This article wishes to claim that the heralds of Zionism were Orthodox rabbis, such as R. Kalisher, R. Alkalai, R. Friedland, R. Guttmacher, R. Bibas, and R. Natonek, who operated in the early half of the 19th century and transformed the Jewish theology that advocated a passive-spiritual-Divine redemption into an active-practical-natural redemption. For this purpose, it is necessary to immigrate to the Land of Israel and cultivate the land. They contended that once the People of Israel would do so, the redemption would arrive.
\end{abstract}

Keywords: heralds of Zionism; R. Kalisher; R. Alkalai; redemption; Zionism; labor; the Land of Israel; Jewish theology

\section{The Heralds and Their Identification}

Historiographical research contains an approach that perceives the ideologues who preceded the Hovevei Zion movement (1881) and the Zionist movement (1896) as "heralds of Zionism", also known as "proto-Zionists", or sometimes "proto-nationalists". These thinkers acted upon, or at least proposed the idea of the Jews' return to the Land of Israel and establishment of a political entity therein, beginning from the 1860s. The researchers are divided, however, on the identification of the heralds. Some locate them even earlier, in the 17th century, while others deny their very existence (Goldstein 2016, pp. 29-37).

Sokolow claimed that the first heralds of Zionism were 17 th-century rabbis. ${ }^{1}$ As he saw it, anyone who wished to immigrate to the Land of Israel was a Zionist (Sokolow 1919). Dinur defined R. Judah Hehasid, who immigrated to the Land of Israel in 1700, as a "herald". This opened a new era in Jewish history, similar to those of productivization, the Hebrew language, and immigration to Israel (Dinur 1995). Weinreb defined anyone who wished to solve the problem of the Jews as a "herald", and this began in the 19th century (Weinreb 1937). Katz defined three "heralds": R. Zvi Hirsch Kalisher, R. Judah Alkalai, and the socialist Moses Hess. In his opinion, they were the initiators of the movement "in the real historical respect" and through their actions, beginning from the 1860s, they brought about the establishment of the Hovevei Zion movement (Katz 1950). The test was one of "social productivity", i.e., to what degree is social influence transformed into an idea (Katz 1980). Many historians embraced this approach (Salmon 1998).

In contrast, there were those, such as Citron, who argued that the heralds had no part in the establishment of Hovevei Zion or the Zionist movement (Citron 1914, p. 73). In time, some, such as Ettinger, embraced this claim (Ettinger 1969, Part III, pp. 179-80). As Ettinger saw it, the events of the 1860s-1870s events were merely a passing episode that left no mark on Zionism; the heralds (whom he did not acknowledge) were motivated by hopes of emancipation, while the Zionist movement was disillusioned by it. Jewish nationalism is a modern phenomenon and therefore not associated with rabbinical activity and conceptions. In his opinion, the members of Hovevei Zion were the heralds of Zionism. 
This was also the approach of Goldstein and Stanislavsky, who claimed that the "heralds" had no impact. They were only recognized as "heralds" in the 20th century, when the Zionist parties developed their narrative. At that time, the socialists associated themselves with the socialist Moses Hess and the religious Zionists with R. Kalisher and R. Alkalai (Stanislavski 2016, pp. 11-13).

\section{A New Definition}

Although the criticism is justified, the claim that the heralds only began operating in the $1860 \mathrm{~s}$ is inaccurate. Some were active in the 1820s and 1830s, before the 1848 "Springtime of Nations". The identification of Moses Hess as a herald of Zion is indeed problematic. He published his book "Rome and Jerusalem" in 1861 but had very little influence. Approximately 40 years later, Herzl became aware of the book and embraced some of its ideas. Hess' inclusion as a herald of Zionism appears to have been a later occurrence within the secular-Zionist narrative, as all the other heralds were rabbis.

I would like to present the argument that the heralds of Zionism were Orthodox rabbis, such as R. Kalisher, R. Alkalai, R. Friedland, R. Guttmacher, R. Bibas, and R. Natonek, who operated in the early half of the 19th century and transformed the Jewish theology that advocated a passive-spiritual-Divine redemption into an active-practicalnatural redemption. To promote the latter type of redemption, it is necessary to immigrate to the Land of Israel and cultivate the land.

The mainstream version of the redemption was that it will come from heaven and no human action can hasten it. Even the Temple had descended from heaven with no human involvement. The source of this contention was the verse: "I adjure you, O maidens of Jerusalem ... do not wake or rouse love until it please" (Song of Songs 2:7), which was the source that underlies resistance to hastening the redemption (Bavli Ketobut 111a). In contrast, the heralds of Zionism claimed that the redemption would be natural, brought about through human effort. They based their contentions on the Kabbalah and on rabbinical literature. The kabbalist view contends that an "arousal from below" (it'aruta diletata), by humans, will lead to an "arousal above" (it'aruta dele'ela), in the Divine world, which will hasten the redemption. Rabbinical literature too relates to the human endeavors that must come first: "The Holy One said to Israel: My children, open to Me ... an opening as small as the eye of a needle and I shall make an opening in Me for you so wide that through it wagons and coaches could enter" (Shir Hashrim Rabah 5:2). However, the beginning must come from human beings, from below.

R. Bibas and R. Kalisher also called for establishing a Jewish army. They contended that once the people of Israel do so, the redemption would arrive. Hence, in my opinion, the heralds of Zionism were rabbis who generated a theological-religious revolution, while the historians mentioned above focused on the social-political enterprise of specific figures and therefore identified the heralds of Zionism differently and in later periods than those I shall discuss in this article. In order to understand this theological revolution, that preached a natural redemption and a proactive Jewish approach, I shall cite R. Shalom Dov Schneerson, the fifth Lubavitcher Rebbe (and the leader of the Chabad Chasidic sect). He voiced his ideas in 1900 but I will cite him nonetheless, as his words reflect the concept of passive miraculous redemption that was dominant among the rabbis and the Jewish public in general, emphasizing the daring nature of the proactive approach.

The rebbe claimed that the political-Zionist awakening is a denial of the Messianic faith. The efforts performed as part of this awakening constitute a forcing of the Messianic era and are forbidden. Redemption is a divine process that cannot be hastened by human action. The rebbe rejected any activism, even if enacted by religious people. "We must not listen to them in this matter of advancing our redemption through our own power, as we are not entitled to force the Messianic era, including to plead for it (Based on Rashi, Bavli, Ketubot 111a), and all the more so by means of corporeal forces and schemes" (Landa and Rabinowicz 1900, p. 57). It is imperative to be completely passive and it is even forbidden to strongly pray for a hastening of the redemption, not to mention practical 
actions. Human involvement in the redemption, even if it shall succeed, will be partial and temporary. It is necessary to wait for a redemption that is completely from God Himself, and then it shall be complete and eternal:

Because even the redemption effected through Moses and Aaron was not a complete redemption, and [Israel became enslaved] once again [in Babylon]; all the more so the redemption that was effected through Hananya, Mishael, and Azarya [as they became enslaved once again to the ancient Greeks], even though they followed the words of Jeremiah and of the latter prophets who were with them. And in the current exile we must only anticipate our redemption and salvation by God Himself, not through human beings, and our redemption will be complete. (Schneerson 1982, Part I, p. 122)

Therefore, any endeavors undertaken to hasten the redemption must be undermined. The passive redemption approach is also evident in the words of R. Samson Raphael Hirsch, a revolutionary in his own right and the "father of modern Orthodoxy". Nonetheless, he espoused the classical passive conception and rejected activism (Horwitz 1998). He wrote to R. Kalisher: "And we have never taken upon ourselves the path of redemption through enhancement and rectification of holy land, rather through enhancement and rectification of our hearts" (Hirsch 1951, p. 12). He refused to support the Jewish settlement in the Land of Israel and wrote: "Because that which they consider a major good deed, I perceive as a considerable offense" (Hildesheimer 1986, p. 199). As he saw it, "Not to try once again by their own power to establish national independence, rather this national future should be left to the discretion of God's leadership alone" (Hirsch 1992, p. 148). Activism is an offense.

In order to further elucidate this theological revolution, one should understand that there are two Jewish identities that evolved in ancient times. One was the biblical-Jewish identity, described in the Bible; and the second was the rabbinical-Jewish identity, described in rabbinical literature from the 1 st to the 6 th centuries. The Bible provides a portrayal of the biblical Jew. This was a man of labor who engaged particularly in farming, took part in military bouts, and maintained a family. The biblical Jew resembled all people of his time, but he was distinguished as a Jew by his faith in a single God. This explains why the Books of the Prophets center on the conflict between monotheism and polytheism. The biblical Jew remained the sole Jewish identity until after the repression of the three major revolts: the Great Revolt (66-73CE), the Kitos war (115-117CE), and the Bar-Kochba Revolt (132-135CE) (Mashiach 2012).

The failure of the revolts brought about the political elimination of Judah, the Second Temple was destroyed, and many residents of Judah and the Diaspora were killed. Then, with the political and military leadership eradicated, the Sages assumed leadership. Following these bloody events, which resulted from the Jewish-offensive ethos, it appears that the Sages reached a strategic decision to change the Jewish ethos from offensive to defensive (Mashiach 2014, 2016, 2020a). The national task, as they saw it, was to survive the period of exile as Jews.

The identity of the biblical Jew is countered by the identity of the rabbinical Jew, who neither worked nor fought. Moreover, the Sages preached passivity and subservience. They did this, among other things, by introducing interpretive contents into concepts such as freedom, bravery, and war. For instance, the concept of freedom in the Bible refers to legal freedom. A free person (ben horin) is one who has no master. The Sages gave the concept of freedom a different meaning. From now on, freedom was no longer legal, rather conscious-religious: 'There is no free man except one that involves himself in Torah learning' (Mishna, Tractate Avot, 6:2). There was no longer any need to rebel and to remove the yoke of the enslaver; from now one he who studied Torah was free by virtue of this practice. This consciousness-related concept of freedom neutralized the desire to rebel.

Another concept is that of bravery-the lexical definition of bravery is 'a human virtue normally manifested in performing, or willingness to perform, acts of bravery at the cost of risks and self-sacrifice.' Indeed, the concept of bravery in the Bible relates to 
physical bravery as manifested on the battlefield. An example is David's thirty braves who displayed their bravery on the battlefield (II Samuel 23:8-39; I Chronicles 11:11-47). For the Sages, however, physical-militarist bravery was transformed into cognitive-psychological bravery: 'Who is the mighty one? He who conquers his impulse' (Mishna, Avot 4:1). No longer bravery in the heat of battle versus the enemy, rather the bravery of a person who manages to overcome his own urges. So too was the concept of war transformed. Where in the Bible the concept of war bears simple meaning, the concept of war in rabbinical literature becomes associated with 'the war of Torah' (Bavli, Megillah 15b; Bavli, Hagiga 14a; Bavli, Sanhedrin 42a)—no longer fighting per se, rather fighting in the study hall with regard to a halakha, sevara [reasonable explanation], or prayer. For example, the rabbinical interpretation of Jacob's words: "which I wrested from the Amorites with my sword and bow" (Genesis 48:22). "With my sword and bow" were translated into my prayer and plea (Bavli, Bava Batra 123a). In this way, one of David's braves, Benayahu ben Yehoyada, was designated 'head of the Sanhedrin' (Bavli, Berachot 3b; Bavli, Sanhedrin 16b). Namely, not a military brave, rather a brave in the war of Torah, who wages battles concerning Torah conjectures in the study hall.

Furthermore, the Sages preached subservience and bending oneself. No longer is a Jew encouraged to defend his honor, rather to bow his head when encountering evil people and deeds. 'If wicked people come upon a person, he should bend his head before them' (Bavli, Yevamot 121a). Additionally, another counsel: 'A person should always be soft like a reed, and he should not be stiff like a cedar' (Bavli, Ta'anit 20a). The message is the same-a Jew must bend his head and swallow his pride, he must be soft like a reed, of which it is said: 'The reed-all the winds come and blow it and it bends with them. When the winds die down the reed stands in its place ... but the cedar does not stand in its place, rather when a southern wind blows it uproots the cedar and turns it bottom up' (Ibid). This is a completely defensive message. The reed is indeed weak and delicate, but it survives and that is what matters.

Moreover, the Sages augmented their preaching of passivity and subservience with a severe oath that God demands of his people, 'that they should not rebel against the rule of the nations of the world'. This oath is accompanied by a severe threat: 'If you fulfil the oath - it is good, and if not-I will abandon you to those who seek to kill you' (Bavli, Ketubot 111a).

Aside from their interpretations and recommendations, the Sages also changed the entire Jewish scale of values. In their teachings, Torah study became the supreme and exclusive value. Torah study is a religious precept: 'Impress them upon your children. Recite them when you stay at home and when you are away, when you lie down and when you get up' (Deuteronomy 6:7). Nonetheless, interestingly, in the entire Bible there is no role model of a person who actually studies Torah. This is a surprise for all those proficient in rabbinical literature, as the Sages posited Torah study as a supreme value and said: 'But the study of Torah is equal to them all' (Mishna, Pe'ah 1:1). Where biblical characters espoused several values and were engaged in building a life of work, war, family and more, the role models of rabbinical literature are scholars who engage in the study of Torah incessantly, day and night. A different Jewish identity.

This further clarifies the daring innovation undertaken by the heralds of Zionism, theological revolutionaries who called for activism, natural redemption, immigration to the Land of Israel and manual labor in the land, as well as changing the Jewish identity from rabbinical-Jewish identity back to biblical-Jewish identity.

\section{The Teachings of the Heralds of Zionism}

\subsection{R. Zvi Hirsch Kalisher}

R. Zvi Hirsch Kalisher (1795-1874), one of the most prominent heralds of Zionism, called for immigration to the Land of Israel and cultivation of the land, as part of his belief in natural redemption and Jewish activism (Katz 1979, pp. 285-307; Yedidya 2015; Meyers 2003). R. Kalisher began his activities to implement his ideas in the 1830s. In 1836, he met 
with Mayer Anschel Rothschild. R. Kalisher harbored thoughts of renewing the sacrificial rites in Jerusalem. He believed that once the people of Israel would bring the daily offering in the Temple, they would be redeemed (Kalisher 2002, pp. 87-165). He tried to convince Rothschild to purchase the Temple Mount. Rothschild refused.

His ideological sources derived from general philosophy of all eras, medieval Jewish philosophy, and Kabbalah (Baumgarten 2015). Kabbalah led him to an immanent conception of Divinity, whereupon everything that happens in the world is decreed by Divine providence: "We have announced from Kabbalah ... God, may He be blessed, fills all the worlds, and there is no place that is vacant of His honour ... If so, it is very clear that His providence covers all His creature enterprises, no entity in the entire world can move without His knowledge." (Kalisher 1843, Part I, p. 8).

R. Kalisher understood his era as a call from heaven, it'aruta dele'ela in Kabbalistic terms, that must be matched by it'aruta diletata, arousal from below, and then the redemption will arrive. Alternately, he claimed that the arousal from below is what will stimulate the arousal from above, and then the redemption will arrive. "If cultivating our land will be established by our hands, and we will begin the arousal from below in the holy land, then God will undoubtedly command the blessing" (Kalisher 2002, p. 28). The Jewish people must consent by immigrating to the Land of Israel, purchasing land and cultivating the land.

Redemption, as he sees it, is divided in two (Salmon 2015): naturalistic and apocalyptic (Schwartz 1997). The first stage is naturalistic, and it is predicated on human endeavors; the second is apocalyptic, and it depends on Divine will, "A new sky and a new land in spirituality, death will be wiped out forever" (Kalisher 2002, pp. 38-42).

In 1862, he published "Drishat Zion" (Seeking Zion), where he presented his theological teachings. In his opinion, redemption is natural and slow (Shmuel 2002):

The redemption of Israel and the Messiah ... One should not think that the Lord, blessed be His name, will suddenly descend from heaven to earth and say to his people: depart, or that He will suddenly send His Messiah from heaven ... this is not how one with intelligence should understand it! ... The horn of salvation will appear at a slow pace. (Kalisher 2002, p. 37)

Natural redemption depends on human activism, "It is necessary to understand ... that the beginning of the redemption is through human nature, and then God, may He be blessed, will appear among us and among all creatures of the world" (Ibid., p. 68). Additionally, this will be done by means of the Land of Israel and its settlement. "To come to the Holy Land in droves like a swarm of sheep and to transform it into a settled land, because that is the preface to the beginning of the redemption, to build that which was in ruins and to plant that which was desolate" (Ibid., p. 76). Cultivation of the land in the Land of Israel is a religious precept. "The precept of planting the land is in fact a major precept ... it is a religious precept to plant by oneself in order to perform the commandment of settling the land" (Ibid., p. 56).

He also called for establishing a military and police force in order to defend the Jewish settlers: "To prepare therein people knowledgeable in warfare, so that the Arabs will not come ... to destroy that sown and the vineyards, and a 'polizei ordnung' [police force] should be formed to destroy them" (Ibid., p. 130). In order to show how far this went, he declared: "Those who are coming to settle in the Land of Israel, are called the 'Messiah" (Kalisher 1864, p. 10). Jewish activism is the redemption.

In summary, R. Kalisher was a theological revolutionary who believed in natural redemption, human activism and practical work.

\subsection{R. Judah Alkalai}

R. Judah Alkalai (1798-1878) (Rafael 2004), the rabbi of Semlin, Serbia and one of the leading heralds of Zionism, believed in natural redemption and human activism (ibid., Part I, pp. 197-272). Therefore, he called for immigration to the Land of Israel and for cultivation of the land (Katz 1979, pp. 308-56; Lebel 1989). He began to put his ideas 
into writing in 1834, in the booklet "Shma Yisrael" (Hear O Israel) (Shma Yisrael, (Rafael 2004, Part II, pp. 557-70). He claimed that the redemption is natural and slow, and not as many think:

And it shall not cross your mind that the Messianic era and the redemption ... and the coming of our Messiah ... will all come at once and in one day ... because its beginning is slight and unfelt ... Such is the redemption of Israel, at first little by little, and as it grows it increases. (Rafael 2004, Part I, pp. 254-55. Based on the Talmud Yerushalmi, Berachot 1a)

Additionally, he added: "And he who says that the redemption shall begin with the Messiah, son of David, as hoped for by the simplest of the unlearned ... these are inconsequential words ... and in my opinion he who conceals this surreptitiously desecrates God's name" (Ibid).

Additionally, how will the redemption occur? By immigration to the Land of Israel and performing work in the land. He ascribed to physical labor in the Land of Israel supreme theological meaning, and the redemption depends upon this. "Our exile began with clay and bricks and all work in the field, and our redemption will begin with clay and bricks and all work in the field" (Rafael 2004, Part II, p. 689). This means no longer passively waiting for the Messiah, as had been customary, rather physical labor and activism.

Activism is redemption: "Settling the land is the redemption, removing the desolation from the land ... agricultural work is the redemption" (Ibid., p. 763). Therefore, he issued a call:

Redemption is settlement of the Land of Israel ... and the main delay in the coming of the Messiah ... is because things must be rectified ... and these are things that involve the physical aspects of the land ... the beginning of the redemption is to redeem Jerusalem ... to establish colonies ... and the Messiah, the son of David, will not come until the land is settled ... buy estates that are up for sale ... because it is a part in the world to come (Ibid., p. 753).

Not only is work in the land redemption in the current world, it also promises one a part in the world to come. Further on, R. Alkalai based the entire idea of repentance on immigration to the Land of Israel: "This general repentance, namely, that all of Israel will return to the Lord our God, to the land that is the legacy of our forefathers" (Rafael 2004, Part II, pp. 324-25. Statement based on the Talmud Bavli, Ketubot 110b).

In conclusion, R. Alkalai was one of the heralds of Zionism, a theological revolutionary who believed in natural redemption, human activism, immigration to the Land of Israel and cultivation of the land.

\subsection{R. Judah Bibas}

R. Judah Bibas (1789-1852), the rabbi of Corfu, Greece, was one of the first heralds of Zionism, and influenced R. Alkalai (Molcho 1957; Bezalel 2008, pp. 120-34; Weiler 2015). His writings no longer exist. We received the information about him and his revolutionary conceptions from R. Alkalai, who met with him in 1839 (Rafael 2004, Part I, pp. 1-30. R. Alkalai formulated his ideas before meeting R. Bibas, as he published Shema Israel in 1836) and called him "a holy man of God", "the exceptional rabbi", "the Divine Kabbalist" (ibid., Part I, p. 20), as well as from the testimony of two Scottish missionaries who spoke with him in 1839 (Bonar and M'Cheyne 1842).

R. Bibas called upon people to cease waiting for a miraculous-Divine redemption. Redemption, as he saw it, depends on human activism. He called for repentance, meaning immigration to the Land of Israel and cultivation of its land. He also called to establish a Jewish army to conquer the Land of Israel from the Ottoman Empire. "The haluka (money sent to support the Jews of Jerusalem) in the holy land should be cancelled, and Jews should work and even wield a bayonet when necessary" (Bonar and M'Cheyne, p. 380). 
Following popular opinion, he believed that redemption depends on arousal from below that will arouse the Divinity from above. Therefore, the people of Israel must immigrate to the Land of Israel and hasten the redemption.

And it is already known that arousal from above depends on arousal from below, and the Holy One blessed be He said ... return to me and I will return to you ... it depends only on repentance ... this means the return of the Israelites to their land ... and when the Israelites will make an effort to immigrate towards Jerusalem ... the compassion of the Holy One blessed be He will immediately be aroused and He will reveal his redemption in the near future. Amen (Rafael 2004, Part I, pp. 20-21)

R. Bibas witnessed the Greek revolt against the Ottoman authorities in 1821-1832. The revolt led him to the insight that if the Greeks can do it than the Israelites can too. Therefore, "it is necessary to guide the Jews in science and weapons so that they will be able to seize the Land of Israel by force from the Turks ... just as the Greeks took their land by force" (Benvenisti and Haim 1958, Part II, p. 53). R. Bibas called to include in the curriculum also "studies of the seven wisdoms or sciences, such as music, astronomy, etc.", in order to provide the Jews with training. No more social isolation and engaging in spirituality alone, rather engaging in labor and in warfare, in order to redeem the Land of Israel and hasten the redemption. In this way, "the face of the universe will be illuminated" (Molcho 1957, p. 30).

In summary, R. Bibas was one of the heralds of Zionism, a theological revolutionary who called for natural redemption, activism, immigration to the Land of Israel, its occupation and cultivation of the land.

\subsection{R. Eliyahu Guttmacher}

R. Eliyahu Guttmacher (1796-1874) was the rabbi of Graetz, Germany. He was one of the greatest heralds of Zionism, an adjudicator and a kabbalist (Rafael 1958-2000, Part I, pp. 447-56). He was also a revered rabbi who served as an Admor (a chasidic leader) in Germany, although he did not see himself as such and in Germany this was not customary. He was a friend of R. Kalisher, though they each reached their insights independently.

His disciples attested (Guttmacher 1984, p. 8) that his occupation with Kabbalah led him to a mystical method whereby the Jews, the Torah and the Divinity form a type of triangle that is fully realized in the Land of Israel. In his opinion, following the sins of Israel the triangle became separated and the Israelites were sent into exile. Once the three elements will be united the redemption will arrive.

R. Guttmacher too claimed that the redemption is natural and depends on human rather than on Divine-miraculous activism:

Many mistakenly think that they can remain ... as usual at home, and the gates of mercy will suddenly open ... and all the prophets' designations will come true ... but that is not so. What was more certain than the end of the seventy years in Babylon, which was designated to begin with as the ultimate duration that was to last no longer, but still Daniel made all his efforts ... and Nehemia drew close to the natural method, but no one said like the cynics: Sit and wait, the redemption will come. (Slutzky 1892, Part II, p. 41)

The redemption depends on the people of Israel, like the kabbalistic method that predicates the arousal from above upon arousal from below, meaning the settlement of the Land of Israel: "I have much proof that the redemption will emerge promptly once final actions will be taken to settle the Land of Israel" (Ibid., p. 44).

He believed that once there are 130 Jewish families in the Land of Israel, the redemption will occur. Efforts must begin from below, by settling the Land of Israel and cultivating the land, and then God will complete the redemption from above. "It is already clear to me that if the Israelites will begin by cultivating the holy land by a total of 130 families, the redemption will commence even if the Israelites are not worthy of it ... that is what 
should be done, redeeming the land-we should begin and God will do the rest" (Ibid., pp. 41-42). The redemption will occur even if the people of Israel are unworthy, but it must be initiated from below.

In summary, R. Guttmacher was one of the heralds of Zionism, a theological revolutionary who believed in natural redemption, settlement of the Land of Israel and cultivating the land.

\subsection{R. Nathan Friedland}

R. Nathan Friedland (1808-1883) was a sermonizer in Taurig, Lithuania. One of the heralds of Zionism, he believed in a natural redemption that would begin with immigration to the Land of Israel, Torah study in the land and cultivating the land. In 1858 he met R. Kalisher, realized that he had found an ally, and became Kalisher's loyal assistant. That year he published Kos Yeshua Unehama (Cup of Salvation and Consolation) (Friedland 1858). His main book is Yosef Chen (Friedland 1878, p. 54). He was among those who influenced Baron Rothschild and Adolf Cremieux to become involved in settling the land and even tried to engage Moses Montefiore and Emperor Napoleon III in this endeavor. He immigrated to the Land of Israel towards the end of his life.

He began acting to realize his vision in the 1840s. He said: "I devoted half my life to caring for the Land of Israel" (Kalisher 2002, p. 198). R. Friedland claimed that the redemption is natural and that it depends on the desire of the Israelites to return to the Land of Israel. The rejection of the Land of Israel began with the sin of the twelve spies (Numbers 13-14), and for this reason the Israelites were sent into exile. It will end when they express a desire for the land: "His people will desire its land, because up to now they have rejected the coveted land ... because this is the main reason for the exile caused by the sin of the spies ... Indeed, the Holy One blessed be He will set in motion the entire world ... through exigencies and duress His people will come to desire their land" (Friedland 1878, p. 59).

He cited his rabbi, R. Zundel of Salant, who claimed that the redemption does not depend on repentance rather on settlement of the land and its cultivation. "It is not repentance that is the hindrance ... when whenever possible the Israelites will come to the holy land of fields and vineyards and the land will give them its yield in abundance, this will be the obvious end of days, and in that generation the son of David will appear" (Ibid., 54). In his words he referred to the Talmud: "You do not have a more obvious end [of days] than this, as it is said: 'But ye, O mountains of Israel, ye shall shoot forth your branches, and yield your fruit to My people Israel; [for they are at hand to come.]"' (Bavli, Sanhedrin 98a, based on Ezekiel 30:8). Additionally, Rashi interpreted on site: "When the Land of Israel shall give its fruit bountifully then the end will be near, and there is no more obvious end than that". The clearest sign of redemption is when the Land of Israel responds to its cultivation and produces fruit. Labor heralds redemption and acts to hasten it. He claimed that settling the land is not complete without labor. "So long as we do not live off the land, which will give us its fruit, it is not considered settling ... because the success of the body and the success of the soul are one, and this begins with physical success, because without flour there is no Torah" (Friedland 1878, p. 43).

In summary, R. Friedland was one of the heralds of Zionism, a theological revolutionary who believed in natural redemption, settling the Land of Israel and cultivating the land.

\subsection{R. Jozsef Natonek}

R. Jozsef Natonek (1813-1892), among the heralds of Zionism, was a rabbi and religious judge in several Hungarian congregations (Frankel 1956; Rafael 1958-2000, Part IV, pp. 2-13). He initiated his revolutionary philosophy in 1850 (Frankel 1956, p. 75). In 1861 he published Mashiach: Masa al Ha'emantzipatzya shel Hayehudim (The Messiah—or On the Emancipation of the Jews) under the pseudonym Ábir Amiéli, where he expressed his objection to Emancipation, which in his opinion requires relinquishing the national Jewish 
identity and might lead to assimilation within the Hungarian nation. He called for renewed Jewish settlement of the Land of Israel and the establishment of a state. The Hungarian authorities confiscated all copies of his book.

In 1862, he formed a friendship with Moses Hess, when he became acquainted with Hess' book Rome and Jerusalem and was struck by the similarity to the course he himself recommended in his confiscated book. In this year he also began his Zionist activity, formed contact with R. Kalisher, and suggested to cooperate in purchasing the Land of Israel from the Ottoman Empire. In 1866 and 1867, he took part in meetings in Germany and Constantinople to raise support for the idea of Jewish settlement of the Land of Israel. In 1872, he began to publish a newspaper in German named "Das Einige Israel". Jacob Herzl, father of Theodor Herzl, subscribed to the newspaper, and Natonek was a frequent guest at his home. "Herzl junior undoubtedly heard about the opinions of R. Natonek or even read his writings" (Rafael 1958-2000, Part IV, p. 13).

In the winter of 1850-1851, he wrote Hahitgalut Ha'elohit al yedey Moshe (On the Divine Revelation to Moses), of which only one copy remains. He noted how he had been influenced by the Hungarian War of Independence and the other European revolutions, which stimulated him to ask: If various nations manage to become liberated and achieve independence, why isn't the Jewish people rousing itself to become liberated and achieve a state of its own?

R. Natonek believed in natural redemption, in contrast to most Hungarian rabbis. This led to his dismissal and to criticism towards him. He said that the exile had caused an extinguishing of national sensations and that the concepts of the Messiah, resurrection of the dead and life in the world to be, which had originally borne national meaning, had lost their national content and received religious-spiritual meaning. The political designations had become abstract and were left to the Messiah, who would appear to redeem them. $R$. Natonek thought that redemption depends on us and therefore called for arousal of the people to take action for national revival. "We cannot wait for the Holy One blessed be $\mathrm{He}$ to liberate His people miraculously. We must take the first steps and God will certainly help us as He has promised" (Ibid., p. 5).

In the pamphlet Hahitgalut Ha'elohit (The Divine Revelation), he called to take the initiative rather than rely on the nations of the world:

The people of Israel, to whom God generously granted the very best mental qualities, must not beg foreign nations for a few crumbs of equality from the nations, while capable of extensively enjoying their own national independence (Ibid., pp. 6-7).

Now is the time. "The Divine Providence has chosen our era in which to realize the miracles in practice" (Ibid., p. 7). As he sees it, the Messianic designation has three stages (Frankel 1956, pp. 69-70):

A. Faith in the political Messianic designation.

B. Realization of the political Messianic designation.

C. CRealization of the prophetic Messianic designation.

Concerning the first stage, he wrote that it is necessary to have faith in the national dimension of Israel, as the Jewish identity is comprised of a national and a religious identity. Therefore, the people of Israel are entitled to return to the land of their forefathers. Concerning the second stage, he wrote that it is necessary to act to realize the politicalMessianic designation, which will occur when the Israelites return to their land and establish a state therein. Concerning the third stage, he wrote that realizing the redemption and the designation of the prophets means a Jewish state in the Land of Israel, a course of action that will have a universal impact, "a light unto the nations":

My dispersed people cannot relinquish their national revival, particularly because they are intended for a great Divine designation: just as they reveal the true God in the world, and for this purpose were deported from their land, in order to spread the light of the faith in the West, thus they were intended to display 
benevolence to the people of the East, by bringing them too the achievements of the West ... so that all nations of the world will recognize the true faith and accept it, and in this way the designation of the Messiah will be realized, i.e., faith and the path of democracy will become one concept. (Mashiach: Masa al Ha'emantzipatzya, chp. 8)

In summary, R. Natonek was among the heralds of Zionism, a theological revolutionary who believed in national redemption, settling the Land of Israel and establishing a state therein.

\section{The Reasons for the Theological Revolution}

Several factors led the heralds of Zionism to the recognition that the redemption shall be natural and not miraculous and that the people should be encouraged to immigrate to the Land of Israel and cultivate the land. Here are several of them.

Emancipation. This encompasses imparting social and political rights to a population not previously entitled to them, such as the Jews. However, just as Emancipation granted hope it was also a source of disappointment, upon encountering the grave anti-Semitic manifestations proving that nothing had changed and that the Jews can rely only on themselves. Two examples of this were the violent blood libels in Damascus and Rhodes in 1840, which shocked world Jewry (Angel 1978; Frankel 1997).

Another stimulant was the Greek War of Independence, from 1821 until achieving independence from the Ottoman empire in 1832. R. Bibas mentioned this revolt specifically and it inspired him. The uprising joined other European uprisings, such as that in Spain in 1820, France and Poland in 1830, Austria in 1846, and Switzerland in 1847. To this was added the Springtime of Nations, a wave of national uprisings and revolutions in 1848-1849, following the American revolution in 1776 and the French in 1789.

A significant factor was the year 1840, which many Kabbalists perceived as the year of the redemption. This year is mentioned in the Zohar as a special year: "In 5600 [=1840] the gates of wisdom will open above and the springs of wisdom below, and the world will be rectified" (The Zohar, Part I, 116b). Therefore, in this year Jews from the East and West immigrated to the Land of Israel (Morgenstern 1985). Before and after 1840, the Heralds of Zionism understood that it depends only on us. ${ }^{2}$

Another catalyst was British poet Lord Byron, who in 1815 composed his Hebrew Melodies (Israel n.d.). These poems included "Zionist" statements that aroused major enthusiasm. Nahum Sokolow called for a translation of Byron, and in six essays (Hatzfira 63-68, March-April 1890) compared between the different translations. Judah Leib Gordon wrote: "Byron was the first to begin to arouse the Love of Zion and the affection for Jerusalem in these melodies" (Gordon 1884, Part I, p. 70). Lines from his poem "Oh! Weep for those":

"The wild-dove hath her nest, the fox his cave,

Mankind their country,-Israel but the grave"

were widely cited by many Jews. Another example from the poem "The Wild Gazelle":

"Our temple hath not left a stone,

And Mockery sits on Salem's throne".

And in his poem "On Jordan's Banks" he wrote:

"O, in the lightning let thy glance appear;

Sweep from his shivered hand the oppressor's spear:

How long by tyrants shall thy land be trod!

How long thy temple worshipless, O God!".

Another possible source of inspiration was Prof. George Bush of New York (Goldman 1992), who in 1844 published a book based on Ezekiel (Bush 1844). As he saw it, "Despite all the attempts to destroy them, the Jewish people remained alive, in the hope of returning 
to Zion, their homeland. Finding a way of returning the Jewish people to Zion will benefit not only the Jewish people rather humanity as a whole". More than one million copies of the book were sold and it influenced many in the US and around the world.

\section{Influence on Future Generations}

As stated above, some claimed that the heralds of Zionism had no effect on the masses and that they had no connection to the Zionist movement. It is indeed hard to discern the direct success of the heralds, as the Jews of Eastern Europe believed in a miraculous redemption, the Jews of Western Europe believed in Emancipation, and in the Land of Israel the living conditions were harsh. Nevertheless, I wish to claim that the heralds of Zionism did have an influence on Zionism.

The Zionist movement was founded in 1896. However, there was a link between the heralds and Zionism, i.e., the Hibbat Zion movement and the First Aliya in 1882. The spiritual leader of Hibbat Zion was R. Shmuel Mohilever (Salmon 1991). Salmon contended that R. Mohilever was influenced by R. Kalisher and the natural redemption (Salmon 2010). "The future redemption, according to many of the great rabbis and the majority of the people, will be miraculous ... There are also many major sages who think that the redemption ... will follow a natural path ... and I the insignificant think so too" (Fishman 1923).

David Ben Gurion, Israel's first prime minister, recognized Rabbis Alkalai and Kalisher as the architects of the Zionist enterprise. "When ideologues and true seers such as Rabbis Alkalai and Kalisher emerged among the Israelites ... and showed us new ways of realizing the redemption of the people and of the land - then the pioneering spring gushed forth in the hearts of the immigrants among those returning to Zion" (Berholtz 1994).

R. Alkalai's influence on Herzl, whose father Yaakov Herzl subscribed to the newspaper published by R. Natonek, was mentioned above. "Herzl junior undoubtedly heard about the opinions of R. Natonek or even read his writings" (Rafael 1958-2000, Part IV, p. 13). Additionally, Herzl's father was a student of R. Alkalai and helped publish his books. Additionally, his grandfather, Simon Loeb, was the shofar blower in R. Alkalai's synagogue. It is more than probable that Herzl heard, read and was influenced by R. Alkalai (Winkler n.d.).

In summary, the influence of the heralds of Zionism was effected indirectly through Hovevei Zion and R. Mohilever, and directly through the Herzl family and R. Alkalai.

\section{Conclusions and Discussion}

The heralds of Zionism were Orthodox rabbis, theological revolutionaries, who began their activity in the 1820s-1850s. Most of the rabbis and public believed in miraculous redemption and passivity, while the innovation of the theological revolutionaries was in proposing a course of activism, natural redemption, immigration to the Land of Israel, purchasing lands and cultivating the land, national-religious rather than only religious Jewish identity, and according to Rabbis Bibas and Kalisher, also establishing an army.

An additional dimension is the transformation of Jewish identity. To clarify, two types of Jewish identity are known from ancient times: biblical-Jewish and rabbinical-Jewish. The rabbinical-Jewish identity was comprised of several features, for example nationalism. The latter is allegedly a modern concept, but Hastings claimed that the Bible was the first national guideline (Hastings 1997, chp. 1). The construction of a nation consists of several components: literature; an ethnic group that shares a cultural identity and a language; self-consciousness; geographical territory; common faith; and a threat to the national identity. Hence, the Bible is a constitutive element of Jewish nationality. Judaism is a nation-religion. Hastings followed Kohn (Kohn 1944, chp. 2), who posited three measures of Jewish nationalism: the covenant between the people and their God, a shared national memory and the concept of national Messianism. According to Hastings, the people of Israel are the "true first nation" (Hastings 1997, chp. 8). 
Aside from nationalism there are other features of the biblical Jew, such as activism manifested in labor and in having an army. The biblical Jew tilled the Land of Israel and fought in and for it, and therefore had an offensive ethos. In contrast to the biblical Jew, the rabbinical Jew does not work (as a religious value) and does not fight, Torah study is the supreme and only value, the ethos is defensive, and part of defensiveness is passivity (Boyarin 1997).

The rabbinical identity was the Jewish-exilic identity, and therefore when the heralds of Zionism appeared with their ideas of forming a national state, immigrating to the Land of Israel, building an army, becoming farmers and being proactive in bringing about a natural redemption, the theological revolution they preached reflected a revival of the biblical-Jewish identity.

Here, it would also be fitting to examine how the heralds of Zionism and their theological revolution affected Jewish nationalism in future generations. As we know, the generation subsequent to the heralds of Zionism included the Hovevei Zion movement (Mashiach 2021), who gave rise to the First Aliya in 1882, and later on to the Zionist movement headed by Herzl emerged in the following generation, in 1896. This movement, which included the Mizrahi, a religious Zionist movement, led to establishment of the State of Israel in 1948.

Israel's Jewish population consists of three main groups: general secular Zionists, religious Zionists, and ultra-Orthodox society. The first two were strongly influenced by the heralds of Zionism. Each of these groups embraced an ancient Jewish strain of identity, as elucidated above (Mashiach 2014).

More specifically, the theological revolution initiated by the heralds of Zionism consisted, as stated, of a return to the biblical-Jewish identity, espousing as they did activism and the values of productive work. All these were embraced by the Zionist movement (Almog et al. 1994; Shapira 1997), however without religious faith, rather as an initial Jew who fights in his country and tills his land (Shapira 1997, pp. 217-47). These values were strongly emphasized by the ideologues of the Zionist movement and were attributed to the heralds of Zionism (Berholtz 1994; Rafael 1958-2000, Part IV, p. 13; Winkler n.d.). In this context, the words of Zionist leader Yitzhak Tabenkin concerning the Bible are notable:

The Bible affected all generations of the Jewish people not only in its religious value and contents, because the Bible is a spiritual reflection of an active national life, of a nation that occupies a land, of labour ... The formation of the Hebrew character, the unification of the tribes, the primary attitude to the universe, to nature, to love and death, the wisdom of life, its poetry and sorrow, social and national wars-all these are reflected in the Bible in an ingenious artistic simplicity (Tabenkin 1972, pp. 2, 24)

In order to reinstate the biblical Jewish character, the secular Zionists imparted to the Jewish festivals national non-religious contents. For instance, the festival of Shavuot (Pentecost) is celebrated by the religious public as the festival of giving of the Torah. In secular Zionism it is celebrated as the festival of the First Fruit (bikurim), a festival with an agricultural character, as noted in the Bible. The festival of Sukkot (Tabernacles) is celebrated by religious people as a reminder of the tabernacles occupied by the Israelites in the desert. In the Zionist movement, it is celebrated in its agricultural form, as the festival of ingathering of the fruit. The festival of Chanukah is celebrated in the religious world as denoting the miracle of the cruse of oil, which granted it a spiritual rather than military character. In secular Zionism the festival is celebrated as the victory of the Maccabee revolt against the Greeks.

General Zionism was influenced by the heralds of Zionism, although as noted above it added Moses Hess as one of the heralds of Zionism as part of constructing the secular Zionist ethos, as all the heralds were rabbis. Notably, after the Zionist movement began its activities, it initiated a new independent direction with regard forming Jewish identity, a fact that led to the "New Jew" debate. General Zionism was comprised of several subideologies, a fact that led to several styles of the "New Jew", such as Herzl's political 
approach, Gordon's socialist approach, and the spiritual Zionism of Ahad Ha'am; however, one way or another they were all influenced by the heralds of Zionism (Avineri 2010; Conforti 2009).

The second sector is the religious-Zionist sector. It was influenced by the heralds of Zionism and the theological revolution, which reinstated the biblical-Jewish identity, espousing active action with regard to the redemption and the values of productive work, including of course commitment to faith and halakha. The heralds of Zionism are wellknown figures in all religious-Zionist households. They are taught about at religious-Zionist schools as exemplary figures and their teachings are taught in religious-Zionist yeshivas. Many streets in religious-Zionist neighbourhoods are named for the heralds of Zionism as they are the founding fathers of the movement. Activism and the values of productive work, side by side with Torah study and faith, underlie the slogan of the religious Zionist youth movement, Bnei Akiva — "Torah Va'avoda", i.e., Torah and labor. Hence, in Israeli society, religious Zionists are evident everywhere and in all fields of activity, whether spiritual or material, military or civilian (Mashiach 2020b).

The third sector mentioned, the ultra-Orthodox sector, was not influenced by the heralds of Zionism at all. The ultra-Orthodox are not part of the Zionist movement or of its vision. This sector is divided into two main parts. The first are not Zionist but cooperate with state institutions, vote in elections, and occupy political roles. The second object to the Zionist movement and the state. Moreover, the identity of the ultra-Orthodox is rabbinical rather than biblical and they do not believe in active action, rather in passivity. Nothing is done to facilitate the redemption; the Messiah is awaited passively. The ultra-Orthodox do not believe in the value of labor as a religious value. Work, as they see it, is merely a subsistence need. The only value in which the ultra-Orthodox sector believes is that of Torah study (Ravitzky 1993, pp. 27-35).

In summary, the theological revolution of the heralds of Zionism had a huge impact on secular and religious Jewish identity in modern times. In a process that took many years, from the heralds of Zionism through Hovevei Zion, the Zionist movement, and until the establishment of the State of Israel, their endeavors appear to have met with success.

Funding: This research received no external funding.

Institutional Review Board Statement: Not applicable.

Informed Consent Statement: Not applicable.

Data Availability Statement: Not applicable.

Conflicts of Interest: The author declares no conflict of interest.

\section{Notes}

Author's note: The conventional abbreviation of the honorific term "Rabbi" will be substituted in this article by the letter R. I shall not discuss the controversy concerning the opinion of the Gaon of Vilna and Kol Hator, see: (Morgenstern 2002; Etkes 2005).

\section{References}

Almog, Shmuel, Jehuda Reinharz, and Anita Shapira, eds. 1994. Tziyonut Veda. Zionism and Religion. Jerusalem: Zalman Shazar Center. Angel, Marc D. 1978. The Jews of Rhodes. New York: Sepher-Hermon Press.

Avineri, Shlomo. 2010. Hara'ayon Hatzioni Ligvanav (The Zionist Idea and Its Variations). Tel Aviv: Am Oved.

Baumgarten, Eliezer. 2015. Harav Kalisher: Dat, Kabbalah, Vefilosofya (R. Kalisher: Religion, Kabbalah, and Philosophy). In Et Lehenena. Edited by Asaf Yedidya. Jerusalem: Yad Ben Zvi, pp. 130-49.

Benvenisti, David, and Mizrahi Haim. 1958. "Rabi Yehuda Bibas Vekehilat Corfu Bizmano" (Rabbi Yehudah Bibas and the Community of Corfu of his Day). In Sefunot_Sefer Shana Leheker Kehilot Yisrael Bamizrah (Sefunot_Yearbook for Research of Jewish Congregations in the East). Edited by Meir Benayahu. Jerusalem: Yad Ben Zvi and The Hebrew University, Part II. p. 53.

Berholtz, Esti. 1994. Mevasrey Hatzionut-Mahapecha Beretzef Hamasoret" (The Heralds of Zionism-A Revolution in the Continuity of Tradition). Taleley Orot 5: 250.

Bezalel, Yitzhak. 2008. Noladetem Zionim [You Were Born Zionists]. Jerusalem: Yad Ben Tzvi, pp. 120-34.

Bonar, Andrew Alexander, and Robert Murray M'Cheyne. 1842. A Narrative of a Mission of Inquiry to the Jews from the Church of Scotland in 1839. Edinburgh: Presbyterian Board of Publications. 
Boyarin, Daniel. 1997. Unheroic Conduct. California: University of California Press.

Bush, George. 1844. The Valley of Vision; or, The Dry Bones of Israel Revived. New York: Saxson and Miles.

Citron, Samuel L. 1914. Toldot Hibbat Zion (History of Hibbat Zion [Hovevei Zion]). Odessa: The Odessa Committee of the Hovevei Zion, Part I. p. 73.

Conforti, Yitzhak. 2009. "Hayehudi Hehadash Bamahshava Hatzionit: Leumiyut, Ideologya Vehistoriograpya" (The New Jew in the Zionist Movement: Ideology and Historiography"). Yisrael 16: 63-96. Available online: http://humanities1.tau.ac.il/zionism/ templates/ol_similu/files/israel16/Israel16_conforti.pdf (accessed on 2 May 2021).

Dinur, Ben-Zion. 1995. Bemifne Hadorot (The Changing of the Generations). Jerusalem: Mosad Bialik.

Etkes, Immanuel. 2005. “Hagaon Mivilna Vetalmidav Ke'tzionim Rishonim'—Gilgulav shel Mitos” (The Gaon of Vilna and his Students as 'First Zionists'-The Metamorphoses of a Myth). Zion 80: 69-114.

Ettinger, Shmuel. 1969. Toldot Am Yisrael, III: Toldot Am Yisrael Ba'et Hahadasha (The History of the People of Israel, III: The History of the People of Israel in Modern Times). Tel Aviv: Dvir, Part III. pp. 179-80.

Fishman, Judah Leib, ed. 1923. Sefer Shmuel. Jerusalem: Histadrut Hamizrahi, pp. 153-54.

Frankel, Dov. 1956. Reshit Hatzionut Hadatit Hamodernit, Harav Yosef Natonek. The Beginning of Modern Religious Zionism, R. Jozsef Natonek. Haifa: Hasifriya Hatziyonit.

Frankel, Jonathan. 1997. The Damascus Affair: "Ritual Murder," Politics, and the Jews in 1840. Cambridge: Cambridge University Press.

Friedland, Nathan R. 1858. Kos Yeshua Unehama. Bresslau: Zoltzbach Press.

Friedland, Nathan R. 1878. Yosef Chen. Warsaw: Goldman Press, p. 54.

Goldman, Shalom. 1992. Professor George Bush: Hibraist Amerikani Veproto-Tzioni Professor George Bush: American and ProtoZionist Hebraist. Hadoar 71: 16-19.

Goldstein, Yosi. 2016. Anu Hayinu Harishonim: Toldot Hibbat Zion 1881-1918 (We Were the First: History of Hibbat Zion 1881-1918). Jerusalem: Mosad Bialik.

Gordon, Yehuda Leib. 1884. Kol Shirey Yehuda Leib Gordon (All the Songs of Judah Leib Gordon). St. Petersburg: Pines Print.

Guttmacher, Eliyahu. 1984. Aderet Eliyahu. Jerusalem: Mossad Harav Kook.

Hastings, Adrian. 1997. The Construction of Nationhood: Ethnicity, Religion and Nationalism. Cambridge: Cambridge University Press.

Hildesheimer, Meir. 1986. Rabbi Zvi Hirsch Kalisher Verabbi Shimshon Rafael. In Sefer Aviad (the Book of Aviad). Edited by Yitskhak Refael. Jerusalem: Mosad Harav Kook, pp. 195-214.

Hirsch, Rabbi Shimshon Refael. 1951. Responsa Shemesh Umarpe. New York: Feldheim, Igrot 12.

Hirsch, Rabbi Shimshon Refael. 1992. Sidur Tefilot Yisrael. Jerusalem: Mossad Harav Kook, p. 148.

Horwitz, Rivka. 1998. "Yahaso shel Shimshon Rafael Hirsch Le'eretz Yisrael" (The Attitude of Samson Raphael Hirsch to the land of Israel). In Eretz Yisrael Bahagut Hayehudit Hahadasha (The Land of Israel in Modern Jewish Thought). Edited by Aviezer Ravitzky. Jerusalem: Yad Ben Zvi, pp. 447-66.

Israel, David. n.d. “'Hem Od Yikre'u Li Yehudi'—Mahen Hamanginot Ha'ivriot Ve'ech Ba'u La'olam ('They Will Call Me a Jew'—What Are the Hebrew Melodies and How They Came to Be). Available online: http:/ / www.bgu.ac.il/ \{\}idavid/The\%20Hebrew\%20 Melodies\%20of\%20Byron\%20and\%20Nathan/a.a\%20-\%20hakdama/ma\%20hen\%20hamanginot.pdf (accessed on 3 May 2021).

Kalisher, Rabbi Zvi Hirsch. 1843. Emunah Yeshara. Krotoshin: Monash, Part I. p. 8.

Kalisher, Rabbi Zvi Hirsch. 1864. Hagadah Shel Pesah (Passover Haggadah). Warsaw: Kelter, p. 10.

Kalisher, Rabbi Zvi Hirsch. 2002. Drishat Zion. Jerusalem: Keter, pp. 87-165.

Katz, Yaakov. 1950. "Leberur Hamusag Mevasrey Hatziyonut” (Clarifying the Term 'Heralds of Zionism'). Shivat Zion 1: 91-105.

Katz, Yaakov. 1979. Leumiyut Yehudit (Jewish Nationalism). Jerusalem: Hasifria Hatzionit, pp. 285-307.

Katz, Yaakov. 1980. "Hatnuah Hayehudit Haleumit: NiItuach Sotziology" (The Jewish National Movement: Sociological Analysis). In Beayot Shel Zehut Velegitimatzya Bahevra Hayisre'elit. Problems of Identity and Legitimization in Israeli Society. Edited by Reuven Kahana and Simcha Kuperstein. Jerusalem: Akademon, pp. 18-32.

Kohn, Hans. 1944. The Idea of Nationalism. New York: Macmillian.

Landa, Shlomo Z., and Yosef Rabinowicz, eds. 1900. Or Layesharim. Warsaw: Helater, p. 57.

Lebel, Jennie. 1989. Holeh Ahavat Yerushalayim-R. Yehuda Alkalai-Hareka Hapoliti Vehakehilati Lepoalo" (Sick with Love for Jerusalem-R. Judah Alkalai-The Political and Communal Context of his Actions. Pe'amim 40: 21-48.

Mashiach, Amir. 2012. "Haetos Hayehudi Veteoriyat Hahizdamnut Bitkufat Hameridot Hagdolot Beshelhey Bayit Sheni" [The Jewish Ethos and Opportunism in the Times of the Great Revolts in the 1st and 2nd Centuries A.C.]. Mar'eh 7: 23-49.

Mashiach, Amir. 2014. “Mehayamim Hahem Lazman Hazeh-Nituach Ofi Hamigzarim Bahevra Hayisre'elit Bahoveh, Le'or Hazehuyot Hayehudiyot Meha'et Ha'atika" (From the Days of Old to This Time: A Study of the Sectors of Israeli Society in the Present in Light of Jewish Identities from Ancient Times). Social Issues in Israel 17: 38-68.

Mashiach, Amir. 2016. The Ethos of Masada in Halakhic Literature. Review of Rabbinic Judaism 19: 54-77. [CrossRef]

Mashiach, Amir. 2020a. Religious Zionism-Theology and Social Integration. Israel Affairs 26: 819-32. Available online: https://www. tandfonline.com/eprint/RTXBBFKWYX93VTENYJTC/ full?target=10.1080/13537121.2020.1832321 (accessed on 4 May 2021). [CrossRef]

Mashiach, Amir. 2020b. The Failure of the Major Revolts and its Impact on Jewish Identity. Journal for the Study of Religions and Ideologies 19: 96-109. Available online: https:/ /ixtheo.de/Record/1735693898/Description\#tabnav (accessed on 5 May 2021). 
Mashiach, Amir. 2021. Redemption, Settlement and Agriculture in the Religious Teachings of Hovevei Zion. HTS Teologiese Studies/Theological Studies 77: 1-9. Available online: https://hts.org.za/index.php/hts/article/view/6516 (accessed on 6 May 2021). [CrossRef]

Meyers, Jody. 2003. Seeking Zion-Modernity and Messianic Activism in the Writings of Tsevi Hirsch Kalischer. Portland: The Littman Library of Jewish Civilization.

Molcho, Yitzhak Rafael. 1957. Harav Yehuda ben Shmuel Bibas, Avi Avot Hatzionut Hamedinit. R. Judah ben Samuel Bibas, the forefather of political Zionism. Jerusalem: The Cultural and Educational Committee of the Association of Sephardic Congregations in Israel.

Morgenstern, Arie. 1985. Meshihiyut Veyishuv Eretz Yisrael Bamahatzit Harishona Shel Hame'ah Hayod-tet (Messianism and Settlement of the Land of Israel in the First Half of the 19th Century). Jerusalem: Yad Ben Zvi, pp. 38-65.

Morgenstern, Arie. 2002. "Yahadut Hagola Vehakmiha Lezion, 1240-1840" (Dispersion and the Longing for Zion, 1240-1840). Tchelet 12: $51-100$.

Rafael, Rafael. 1958-2000. Entziklopedia shel Hatziyonut Hadatit (Encyclopedia of Religious Zionism). Jerusalem: Mossad Harav Kook, Part I. pp. 447-56.

Rafael, Yitzhak, ed. 2004. Kitvey Rabi Yehuda Alkalai (Writings of R. Judah Alkalai). Jerusalem: Mossad Harav Kook, Parts I-II.

Ravitzky, Aviezer. 1993. Haketz Hameguleh Vemedinat Hayehudim (The Revealed End and the Jewish State). Tel Aviv: Am Oved.

Salmon, Yosef. 1991. "Harav Shmuel Mohilever-Rabam shel Hovevei Zion” (R. Shmuel Mohilever-The Rabbi of Hovevei Zion). Zion 56: 47-78.

Salmon, Yosef. 1998. "Zramim Ra'ayoniyim—Reshit Haleumiyut Hayehudit Bir'i Hamehkar" (Ideological Streams—The Beginning of Jewish Nationalism as Reflected in the Research). Iyunim Bitkumat Yisrael 8: 565-79.

Salmon, Yosef. 2010. “'Hayehudi Hehadash' Bamahshava Hatzionit-Datit” ('The New Jew' in Religious-Zionist Thought). Yisrael 17: 237-57.

Salmon, Yosef. 2015. "Meshihiyut Vegeula Bemishnato shel Harav Tzvi Hirsh Kalisher" (Messianism and Redemption in the Teachings of R. Zvi Hirsch Kalisher). In Et Lehenena. Edited by Asaf Yedidya. Jerusalem: Yad Ben Zvi, pp. 150-64.

Schneerson, Shalom Dov-Ber. 1982. Igrot Kodesh. New York: Kehat, Part I. p. 122.

Schwartz, Dov. 1997. Hara'ayon Hameshihi (The Messianic Idea). Ramat Gan: Bar Ilan University.

Shapira, Anita. 1997. Yehudim Hadashim Yehudim Yeshanim. New Jews Old Jews. Tel Aviv: Am Oved.

Shmuel, Mohilever. 2002. The Pioneer who Precedes the Camp. Kovetz Hatzionut Hadatit 4: 597-613. First published as 2000, Hasida Rosen, Harav Shmuel Mohilever: Hehalutz Haholekh Lifney Hamahane.

Slutzky, Avraham Yaakov. 1892. Shivat Zion. Warsaw: Sholdberg, Part II. p. 41.

Sokolow, Nahum. 1919. History of Zionism, 1600-1918. London: Longmans.

Stanislavski, Michael. 2016. Zionism: A Very Short Introduction. New York: Oxford University Press, pp. 11-13.

Tabenkin, Yitzhak. 1972. Devarim (Collected Works). Tel Aviv: Hakibbutz Hameuchad.

Weiler, Israel Yael. 2015. “Dat, Leumiyut, Uvesorah Hadasha: Harav Dr. Judah Arie Leon Bibas Mevaser Hatzionut” (Religion, Nationalism, and New Tidings: R. Dr. Judah Arie Leon Bibas the Herald of Zionism). In Et Lehenena. Edited by Asaf Yedidya. Jerusalem: Yad Ben Zvi, pp. 50-69.

Weinreb, Dov. 1937. "Yesodot Hatziyonut Vetoldoteha" (Foundations of Zionism and its History). Tarbiz 8: 69-112.

Winkler, Ruth. n.d. Meharav Alkalai ve'ad Dr. Teodor (Binyamin Zeev) Herzel—Hamekasher Vehamavdil Behashivatam" (From Rav Jehudah Alkalay to Dr. Theodor Herzl—Connection and Differences in their Thought), Fourth Annual Conference for Research Students in Political Science. Available online: https:/ /jalkalai.files.wordpress.com/2019/05/d790d79cd7a7d79cd7a2d799-d795 d794d7a8d7a6d79c.pdf (accessed on 7 May 2021).

Yedidya, Asaf, ed. 2015. Et Lehenena. Jerusalem: Yad Ben Zvi. 